\title{
Editorial
}

\section{Corporate governance and the interests of depositors}

Journal of Banking Regulation (2006) 7, 189-190. doi:10.1057/palgrave.jbr.2350027

The issue of corporate governance is once again on the agenda of the Basel Committee on Banking Supervision with its guidance to enhance corporate governance for banking institutions. ${ }^{1}$ This revision is in light of the growing attention to issues pertaining to corporate governance in the aftermath of the large number of high-profile corporate scandals that have beset the international community over the last several years. These scandals have spawned a whole host of standards and legislative changes to try and improve the governance of boardroom decision-making.

The Basel Committee have emulated the OECD and revised their principles to enhance the principles of corporate governance. However, the Basel principles have been devised to ensure they capture the unique risk profile and, in a much more formal manner, the wider stakeholder interests that exist in banking. The responsibility of bank supervisors is clearly emphasised as it sets out the responsibility they have to keep an eye on and improve corporate governance within the banking system. Bank regulators place a formal responsibility on banks to protect the interests of a number of legal stakeholders such as depositors and regulators apart from the central relationship between shareholders and management. For example, the safety of other stakeholders such as unsecured depositor creditors is limited in general corporate law. In addition to this, bank regulators can also require shareholders to assist with additional finance if need arises to protect the interests of depositors by extending their responsibility. The regulator will first require that a shareholder controller be assessed to gauge whether they are fit and if it is proper for such person to have such a holding in a bank. This is to ascertain the financial shape the acquiring person is in to determine whether the acquisition could put the bank in jeopardy, such as when buyers are in a relatively weak financial position. This is to ensure that the shareholder controllers are aware of their obligation to stand behind the bank if concerns regarding its liquidity or solvency arise.

The relationship between banker and depositor is in law one of debtor and creditor, so it gives rise to a distinct relationship not necessarily one of agent and principal where the former is obliged to inform the depositor of the decisions it makes regarding the risks it places the deposits it accepts other than to pay the deposit back on demand. In the famous bank-customer case Foley v Hill (1848), ${ }^{2}$ the reality of the relationship between bank and customer is clearly espoused, but overlooked somewhat, in terms of providing a rationale for bank regulation and supervision as it highlights the limits with which corporate law protects the interests of depositors as consumers. ${ }^{3}$ According to Lord Cottenham L.C. in describing what risks the bank can expose bank deposits to in Foley $v \mathrm{Hill}^{4}$ he provides, 'the banker is guilty of no breach of trust in employing it; he is not answerable to the principal if he puts it into jeopardy, if he engages in a hazardous speculation'.

The Basel paper sets out eight principles to provide bank regulators and other interested government departments the opportunity to 
evaluate and promote effectiveness of corporate governance arrangements in their respective jurisdictions. ${ }^{5}$ The responsibility for corporate governance is placed on the shoulders of the board of directors and senior management of a bank. The responsibility for creating the right compliance culture rests ultimately rests with them. The board of directors have an obligation to make sure responsibilities are clearly delegated and monitored continuously even on a group wide basis. For example, in the exercise of this responsibility, the board of directors have an obligation to operate the bank in a sound manner and protect the interests of depositors. The day-to-day management of the bank is exercised by senior management in accordance with the strategic aims of the board of directors. The Basel principles also acknowledge the important contribution the external audit and internal audit functions can make to the effectiveness of the board of directors and senior management decision-making. The principles also highlight the importance of banks to operate in a transparent manner and not to have in place a structure or operate in jurisdictions that inhibit effective accountability by stakeholders such as shareholders, market participants and regulators. It is interesting to note the absence of depositors to assist in the accountability process of board of directors of a bank given the limited obligations the board have to give account for their decisions to depositors.

The responsibility of supervisors is to 'promote', 'review' and 'evaluate' a banks compliance with the principles of corporate governance. The Basel paper confers on the supervisor the responsibility to determine whether the systems of corporate governance are commensurate to the size and complexity of the organisation and its operations. It strongly underlines the interests of depositors in any system of corporate governance in banks not just the interests of shareholders. In addition to this, the supervisor is required to put in place procedures to evaluate whether directors and senior management are fit and proper to hold the position.

The Basel Committee in its revised principles to improve corporate governance in banking institutions has certainly attempt to devise a set of principles that reflect the idiosyncratic features of banking business rather than simply emulate the 'generic' principles of good corporate governance that widely exist. It attempts to do this by articulating the context within which banks operate and the risks associated to the business of banking. The move to set the interests of depositors along side the interests of shareholders is warranted in the light of the fact that one of the rationales of bank regulation and supervision is the protection of depositors.

Dalvinder Singh Managing Editor, Oxford Brookes University e-mail: dsingh@brookes.ac.uk

\section{References}

(1) Basel Committee on Banking Supervision, Enhancing Corporate Governance for Banking Institutions, February 2006.

(2) Foley v Hill (1848) II HLC 1002.

(3) Ibid., 1003.

(4) Ibid., 1005-1006.

(5) Basel (2006) at p. 1. 